\title{
Molecular epidemiology of viral haemorrhagic septicaemia virus (VHSV) in British Columbia, Canada, reveals transmission from wild to farmed fish
}

\author{
Kyle A. Garver ${ }^{1, *}$, Garth S. Traxler ${ }^{1}$, Laura M. Hawley ${ }^{1}$, Jon Richard ${ }^{1}$, \\ Jay P. Ross ${ }^{1}$, Jan Lovy ${ }^{1,2}$
}

${ }^{1}$ Fisheries and Oceans Canada, Pacific Biological Station, 3190 Hammond Bay Road, Nanaimo, British Columbia V9T 6N7, Canada

${ }^{2}$ Present address: New Jersey Division of Fish \& Wildlife, Office of Fish \& Wildlife Health \& Forensics, 605 Pequest Rd, Oxford, New Jersey 07863, USA

\begin{abstract}
Viral haemorrhagic septicaemia virus (VHSV) is a fish pathogen found throughout the Northern Hemisphere and is capable of infecting and causing mortality in numerous marine and freshwater hosts. In the coastal waters of British Columbia, Canada, the virus has been detected for $20 \mathrm{yr}$ with many occurrences of mass mortalities among populations of Pacific herring Clupea pallasii (Valenciennes) and sardine Sardinops sagax as well as detections among cultured Atlantic Salmo salar and Chinook Oncorhynchus tshawytscha salmon. We compared nucleotide sequence of the full glycoprotein (G) gene coding region (1524 nt) of 63 VHSV isolates sampled during its recorded presence from 1993 to 2011 from 6 species and a total of 29 sites. Phylogenetic analysis showed that all isolates fell into sub-lineage IVa within the major VHSV genetic group IV. Of the 63 virus isolates, there were 42 unique sequences, each of which was ephemeral, being repeatedly detected at most only $1 \mathrm{yr}$ after its initial detection. Multiple sequence types were revealed during single viral outbreak events, and genetic heterogeneity was observed within isolates from individual fish. Moreover, phylogenetic analysis revealed a close genetic linkage between VHSV isolates obtained from pelagic finfish species and farmed salmonids, providing evidence for virus transmission from wild to farmed fish.
\end{abstract}

KEY WORDS: Salmo salar - Oncorhynchus tshawytscha · Clupea pallasii - Sardinops sagax · Glycoprotein $\cdot$ G gene $\cdot$ Phylogenetic analysis

\section{INTRODUCTION}

Viral haemorrhagic septicaemia virus (VHSV) is an aquatic Rhabdovirus that is 1 of 5 viruses belonging to the genus Novirhabdovirus. Among these viruses, VHSV is unique in its capacity to infect an extremely broad range of fish species. To date, VHSV has been found, either through natural or experimental infections, in over 70 fish species of marine and freshwater fish. Due to the virus' wide host range and transmissibility, VHSV is endemic throughout the Northern
Hemisphere, where certain variants cause substantial economic losses in farmed and wild species.

Historically, VHS disease was thought to be limited to continental Europe in freshwater farmed rainbow trout (Wolf 1988, Smail 1999, Skall et al. 2005). However in 1988, VHSV was isolated for the first time in North America. The detection was made during routine fish health checks on returning adult coho Oncorhynchus kisutch and Chinook O. tshawytscha salmon at 2 different Washington State, USA, hatcheries (Brunson et al. 1989, Hopper 1989). Increased 
viral testing of salmonids over the next several years resulted in 5 more isolations from adult coho again returning to hatcheries in Washington State (Meyers $\&$ Winton 1995). By the early 90s, the host and geographic range of the virus in North America was found to extend from Alaska to California, with isolations occurring in several marine fish species. Mass mortality events of Pacific herring Clupea pallasii (Valenciennes), hake Merluccius productus, and walleye pollock Theragra chalcogramma in Alaska were attributed to VHSV (Marty et al. 1998, Meyers et al. 1999). In British Columbia (BC), Canada, numerous isolations were made from wild Pacific herring and sardines Sardinops sagax, often undergoing epizootic losses. Many of the fish collected from the mass die-offs had external haemorrhagic lesions (Traxler et al. 1999, Hedrick et al. 2003). In addition to isolations made from wild marine fish, VHSV was also detected in farmed Atlantic salmon held in the marine waters of BC (Margolis 1995), representing the first detection in farmed fish in North America. Subsequently, marine net-pen reared Atlantic salmon in Puget Sound, Washington were also found positive for VHSV (Amos et al. 1998).

In 2000, the host and geographic range of VHSV in North America was further extended with VHSVassociated mortality events in wild fish on the east coast of Canada. VHSV was isolated from populations of mummichog Fundulus heterclitus, stickleback Gastersteus aculeatus aculeatus, brown trout Salmo trutta, and striped bass Morone saxatilis (Gagné et al. 2007). Despite this geographic extension of the virus in North America, all virus isolations were restricted to marine or estuarine species. However, in 2005, VHSV in North America was detected in yet another geographic location and in a freshwater species. The isolation was associated with a large mortality event involving freshwater drum Aplodinotu grunniens with a lesser number of round goby Neogobius melanostomus and muskellunge from Lake Ontario (Lumsden et al. 2007). Although this was the first isolation of VHSV in the Great Lakes, analysis of archived samples indicates the presence of virus as early as 2003 (Elsayed et al. 2006). Since the initial detection of VHSV in the Great Lakes, the virus has been associated with mortalities of round gobies in the St. Lawrence River (Groocock et al. 2007) and to date has been isolated in 6 of the 8 US Great Lake states and 2 Canadian provinces, collectively involving over 25 species of fish as well as 1 invertebrate species (Faisal \& Winters 2011).

Molecular epidemiological studies have demonstrated that VHSV can be distinguished into 4 main genetic types (I to IV). These viral types generally correlate with geographic origin of isolation rather than with host species or date of isolation (EinerJensen et al. 2004, Snow et al. 2004). Isolations of VHSV genotypes I, II and III have been localized to European countries, while genotype IV has only been found in Asian and North American waters. Subsequent genetic analyses focusing on VHSV isolations of European and Asian origin further refined phylogenies and demonstrated the existence of several distinct sublineages that predominately reflect VHSV isolations from different populations (i.e. farmed vs. wild fish populations) and/or geographic locations. Strong spatial structuring of VHSV, as demonstrated in these localized studies, has highlighted the need to have a high resolution picture of VHSV genetic diversity throughout the different geographic regions of its infectious range.

The marine waters of $\mathrm{BC}$ represent a VHSV enzootic region with earliest reported detections dating to 1993. However, despite the long-standing historical presence of VHSV in this region, very little is known regarding the genetic diversity of these isolates. To this end, this study was conducted to document both the occurrence and genetic diversity of VHSV isolations made throughout this region. In this study, 63 virus isolates sampled from a total of 29 different locations over a 19 yr period were analysed over the glycoprotein gene sequence region. Furthermore, as this data set includes the first and subsequent occurrences of VHSV in farmed Atlantic salmon, it was of particular interest to determine the origin of the Atlantic salmon pathogenic isolates.

\section{MATERIALS AND METHODS}

\section{Virus isolation and fish losses}

When wild or cultured fish mortality was noticed, samples of live, dead or moribund fish were collected by interested public or fish health personnel for virological analysis. Fish were either placed on ice or frozen depending upon the length of time before samples could be sent to the laboratory for assay. If samples were assayed within $72 \mathrm{~h}$ of collection, the samples were kept on ice; otherwise, the fish were immediately frozen and transferred to the laboratory at a later date. Viral testing of the samples was conducted as described previously (Garver et al. 2007). Briefly, pooled kidney and spleen tissue homogenates from individual fish were inoculated onto epitheioma papulosum cyprini (EPC) and/or Chinook 
salmon embryo (CHSE-214) monolayers. The cells were incubated at $15^{\circ} \mathrm{C}$ and observed several times each week for cytopathic effects (CPE). If CPE were observed, a second passage from the affected cell culture was performed to confirm CPE. Initial virus identity for isolates prior to 1998 was determined using a DNA probe (Batts et al. 1993), while isolations post 1998 were confirmed via VHSV-specific reverse transcriptase polymerase chain reaction (RTPCR) as described below. All BC VHSV isolates listed herein were cultured with the exception of the Pacific Hake isolate which was detected via quantitative RT-PCR (RT-qPCR) (Garver et al. 2011) and RT-PCR.

\section{RT-PCR amplification and sequencing}

Viral RNA from low pass $(<4)$ cell culture amplified virus was extracted using Trizol LS (Invitrogen) reagent following the manufacturer's protocol. Then $5 \mu \mathrm{l}$ of each RNA extract was used as template in $50 \mu l$ RT-PCR reactions targeting the glycoprotein (G) gene. The full coding region of the G gene was assembled from 3 separate RT-PCR amplifications targeting the middle and the $5^{\prime}$ and 3 ' termini of the gene using the primers as designated in Table 1. First round amplification was performed with Superscript One-Step RT-PCR with the Platinum Taq kit (Invitrogen). Each reaction contained $25 \mu \mathrm{l} 2 \times$ Reaction mix, $1 \mu \mathrm{l}$ each $10 \mu \mathrm{M}$ forward and reverse primers (Table 1), $1 \mu \mathrm{l}$ Superscript II RT/Taq mix (Invitrogen) and $17 \mu \mathrm{l}$ ultrapure water. Cycling conditions were $50^{\circ} \mathrm{C}$ for $30 \mathrm{~min}, 95^{\circ} \mathrm{C}$ for $2 \mathrm{~min}$, followed by 30 cycles of $95^{\circ} \mathrm{C}$ for $30 \mathrm{~s}, 50^{\circ} \mathrm{C}$ for $30 \mathrm{~s}, 72^{\circ} \mathrm{C}$ for $1 \mathrm{~min}$, and a final extension at $72^{\circ} \mathrm{C}$ for $7 \mathrm{~min}$. Products were visualized on a $1.5 \%$ agarose gel stained with SybrSAFE gel stain (Invitrogen). If products were not observed after the first round PCR, then $2 \mu \mathrm{l}$ of this PCR reaction was used as template in a second round of amplification containing $5 \mu \mathrm{l} 10 \times$ PCR buffer, $1.5 \mu \mathrm{l} 50 \mathrm{mM}$ $\mathrm{MgCl}_{2}, 1 \mu \mathrm{l} 10 \mathrm{mM}$ dNTPs, $1 \mu \mathrm{l}$ each $10 \mu \mathrm{M}$ forward and reverse primers (Table 1), $1 \mu \mathrm{l}$ Platinum Taq (5 U $\mu^{-1}$ ) (Invitrogen) and $38.3 \mu \mathrm{l}$ ultrapure water. Second round cycling parameters were $94^{\circ} \mathrm{C}$ for $2 \mathrm{~min}, 30 \mathrm{cy}-$ cles of $94^{\circ} \mathrm{C}$ for $30 \mathrm{~s}, 50^{\circ} \mathrm{C}$ for $30 \mathrm{~s}, 72^{\circ} \mathrm{C}$ for $1 \mathrm{~min}$, and a final extension of $72^{\circ} \mathrm{C}$ for $7 \mathrm{~min}$.

PCR products were purified using either a PCR purification kit (Qiagen) or a ExoSAP-it kit (GE Healthcare) according to the manufacturers' protocols. Purified PCR product $(2 \mu \mathrm{l})$ was added to the BigDye Terminator (BDT) cycle sequencing kit (Applied Biosystems) containing the reagents: $2 \mu \mathrm{l} 5 \times$ BDT buffer, $1 \mu \mathrm{l}$ BDT, $0.5 \mu \mathrm{l}$ primer $(3.2 \mu \mathrm{M})$ and $4.5 \mu \mathrm{l}$ ultrapure water. All primer sequences used in sequencing the $\mathrm{G}$ gene are listed in Table 1. Sequencing reaction cycling parameters were $96^{\circ} \mathrm{C}$ for $1 \mathrm{~min}$, and 24 cycles of $96^{\circ} \mathrm{C}$ for $10 \mathrm{~s}, 50^{\circ} \mathrm{C}$ for $5 \mathrm{~s}$, and $60^{\circ} \mathrm{C}$ for $4 \mathrm{~min}$. Sequencing products were purified using the DyeEx spin kit (Qiagen) and run on a 3130xl Genetic Analyzer (Applied Biosystems). Sequencing analysis software (version 5.2, Applied Biosystems) was used for base calling and sequences were edited with Sequencher software (version 4.7, Gene Code).
Table 1. Summary of primers used in the reverse transcriptase quantitative PCR (RTqPCR) amplification and nucleotide sequencing of the full coding region (1524 nt) of the glycoprotein $(G)$ gene. Primer-binding site numbering determined from the VHSV-IVa isolate JF00Ehi1

\begin{tabular}{|c|c|c|c|}
\hline $\begin{array}{l}\text { Glycoprotein } \\
\text { region }\end{array}$ & $\begin{array}{l}\text { Primer } \\
\text { name }\end{array}$ & Sequence $\left(5^{\prime}-3^{\prime}\right)$ & $\begin{array}{l}\text { Location on } \\
\text { VHSV genome } \\
\text { (AB490792) }\end{array}$ \\
\hline \multicolumn{4}{|c|}{ 1st round PCR and sequencing primers } \\
\hline \multirow{2}{*}{$5^{\prime}$} & M466+ & TTA GAC ATG GGA GTG TGA CTT & $2669-2689$ \\
\hline & G784- & TGC CAT TGT GAG CCC CCA & $3714-3731$ \\
\hline \multirow[t]{2}{*}{ Middle } & G330+ & ACT ACC TAC ACA GAG TGA C & $3277-3295$ \\
\hline & G1243- & CAA TTT GTC CCC GAA TAT CAT & $4170-4190$ \\
\hline \multirow[t]{2}{*}{$3^{\prime}$} & G1124+ & GTG GTC AGC ATC AAC TAC AA & $4071-4090$ \\
\hline & NV63- & GGA GAG AAG CTG GTT GTG CTG & $4600-4620$ \\
\hline \multicolumn{4}{|c|}{ 2nd round PCR and sequencing primers } \\
\hline $5^{\prime}$ & G493- & CCA GAT GCA GGA RGG TTC & $3426-3443$ \\
\hline \multirow[t]{2}{*}{ Middle } & G422+ & TCC CGT CAA GAG GCC AC & $3369-3385$ \\
\hline & G1179- & TTC CAG GTG TTG TTT ACC G & $4108-4126$ \\
\hline $\begin{array}{l}\text { Additional } \\
\text { sequencing }\end{array}$ & G776+ & ACA ATG GCA TGC ACG GTG ACA & $3723-3743$ \\
\hline
\end{tabular}

\section{Sequence and phylogenetic analysis}

Consensus sequences for each of the 63 isolates were trimmed to 1524 nucleotides (nt) encompassing the entire G gene coding region. The full length $G$ gene was chosen for molecular epidemiological studies as it has previously provided high resolution typing of VHSV isolates (Einer-Jensen et al. 2005). To identify isolates with identical sequences, consensus sequences were aligned using Sequencher software (v4.7) with the assembly parameter minimum match 
percentage set to 100. Identical G sequences were categorized into sequence types and each type was numbered in chronological order based upon the earliest isolate within each sequence type. The G gene coding sequence of a representative isolate from each of the 42 sequence types was deposited in GenBank with the accession numbers indicated in Table S1 in the Supplement at www.int-res.com/ articles/suppl/d104p093_suppl.pdf. The phylogenetic relationship among VHSV isolates was inferred from single representatives of each sequence type using maximum likelihood and Bayesian approaches with MEGA (Tamura et al. 2011) and MrBayes v3.2 (Ronquist \& Huelsenbeck 2003), respectively. For MrBayes, the mcmc options were as shown in Hall (2011), and convergence was reached at 337000 generations using the general time reversible model (GTR). A 70\% majority rule consensus tree was calculated using sumtree (Sukumaran \& Holder 2010) after the first $25 \%$ were discarded as burn-in. Tree drawing was performed using FigTree (tree.bio.ed. ac.uk/software/figtree/). All taxa used in the analysis and their corresponding accession numbers are provided in Table S1.

\section{RESULTS}

\section{Virus detections}

During the 19 yr collection period spanning from 1993 to 2011, 63 VHSV detections occurred. The features and temporal distribution of the 63 detections are shown in Table 2 and Fig. S1 in the Supplement at www.int-res.com/articles/suppl/d104 p093_suppl. pdf, respectively. Of the 63 detections, $70 \%(44 / 63)$ were obtained from the pelagic species, Pacific herring $(\mathrm{n}=23)$ and Pacific sardine $(\mathrm{n}=21)$, while $25 \%(16 / 63)$ were obtained from farmed Atlantic $(n=13)$ and Chinook $(n=3)$ salmon. The remaining $5 \%$ represented VHSV detections in shiner perch Cymatogaster aggregate $(\mathrm{n}=2)$ and
Pacific hake Merluccius productus $(\mathrm{n}=1)$. Spatially, the VHSV detections originated from 29 different marine collection sites spread over the entire coastal area of BC (Fig. 1). Sixteen of the 29 collection sites $(55 \%)$ were located in the marine waters surrounding Vancouver Island. The majority $(75 \%)$ of the VHSV detections were associated with epizootics or mortality events, with only $25 \%$ stemming from asymptomatic hosts. Among the entire dataset, the predominant occurrence $(68 \%)$ of VHSV detections were observed during the first quarter of the year (January to March) (Fig. 2). See Table 2 for an overview of the features of the VHSV isolates that constitute this study.

\section{Glycoprotein sequence analyses}

Nucleotide sequence comparisons of the entire glycoprotein coding sequence (1524 nt) for the $63 \mathrm{VHSV}$ detections revealed that they fell into 42 sequence types (Table 3 ). Thirty of the 42 sequences were found in single isolates while the remaining 12 types consisted of groups of 2,3 , or 5 isolates each. The maximum pairwise nucleotide diversity among the 63 detections was $2 \%$ (30 nt different out of $1524 \mathrm{nt}$ ) with an overall mean distance of 10.7. A multiple sequence alignment of the 42 sequences generated a consensus sequence that was equivalent to sequence type 13 , which is represented by a single isolate BC 00-397. Consequently sequence no. 13 was used as the reference sequence with which the other sequences were compared. The distribution and number of the genetic differences from the consensus sequence among the $42 \mathrm{BC}$ VHSV sequences are shown in Fig. 3. The variable positions were relatively uniformly distributed along the $1524 \mathrm{nt}$ coding region; however, within the central region of the $\mathrm{G}$ gene, 8 nucleotide positions $(543,551,777,834,846$, 924,1131 , and 1137) were highly variable in the consensus sequence. The majority of nucleotide variants $(72 \%)$ identified in this study do not lead to changes

Table 2. Features of viral haemorrhagic septicaemia virus (VHSV) data set that constitute this study

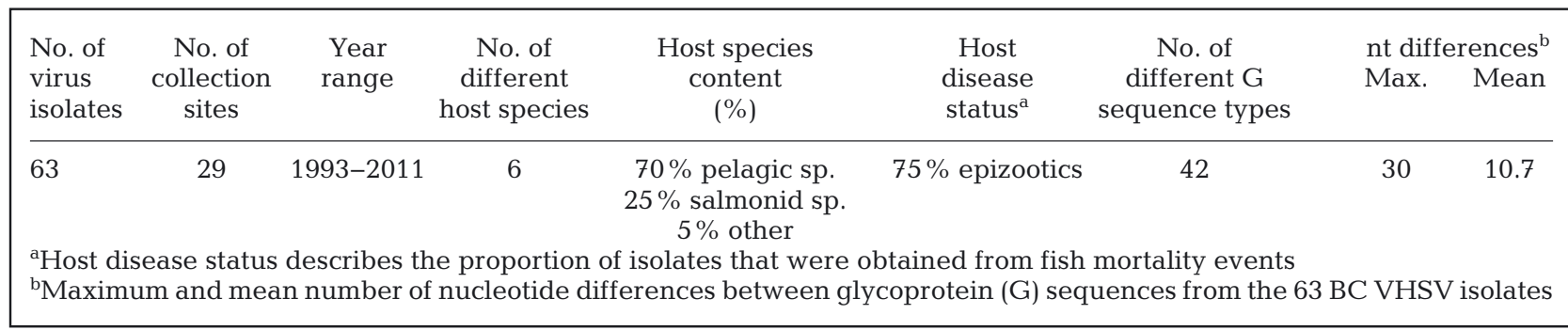




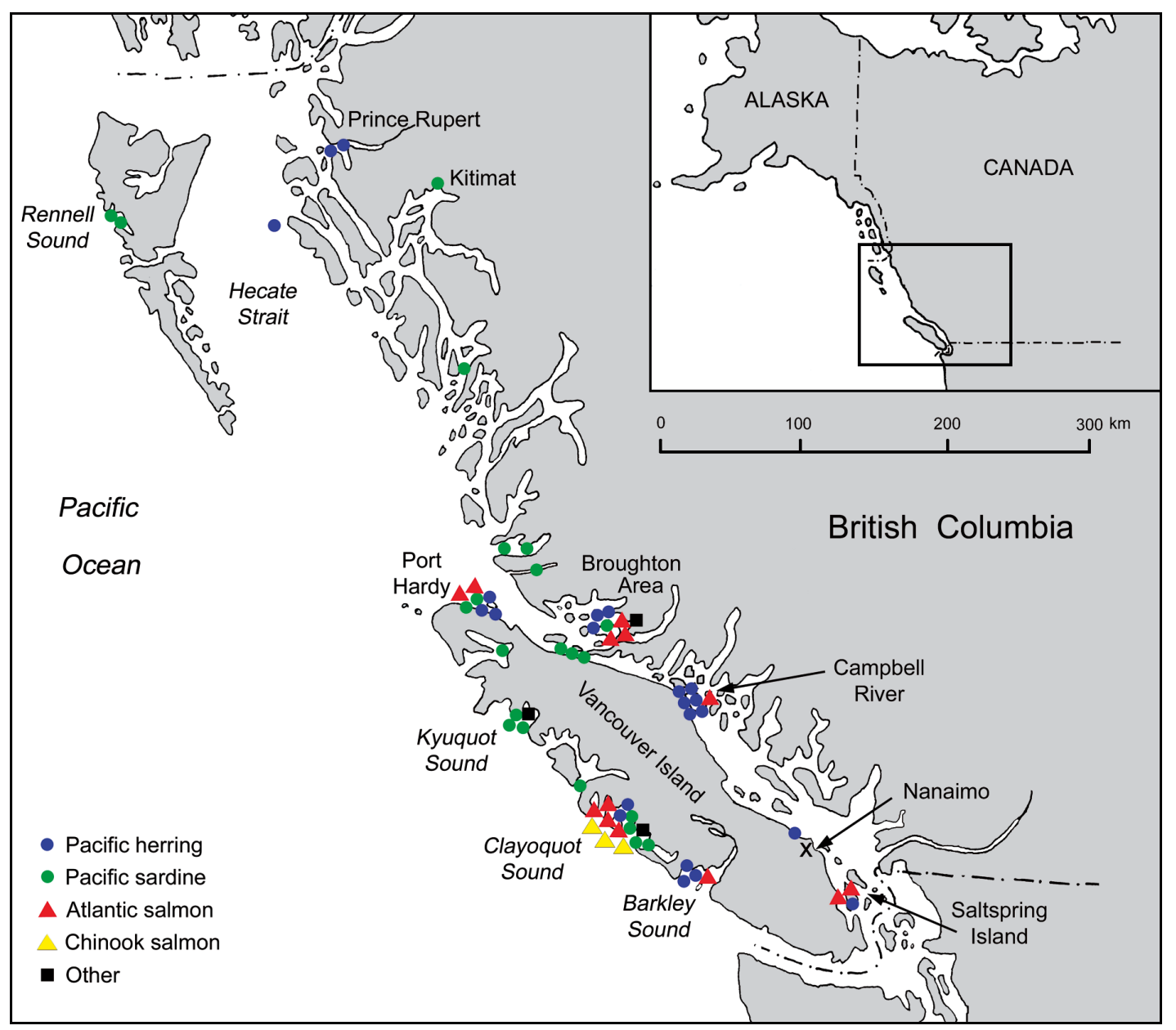

Fig. 1. Geographic location of collection sites for viral haemorrhagic septicaemia virus isolates. X: location of Pacific Biological Station, where laboratory analyses were conducted

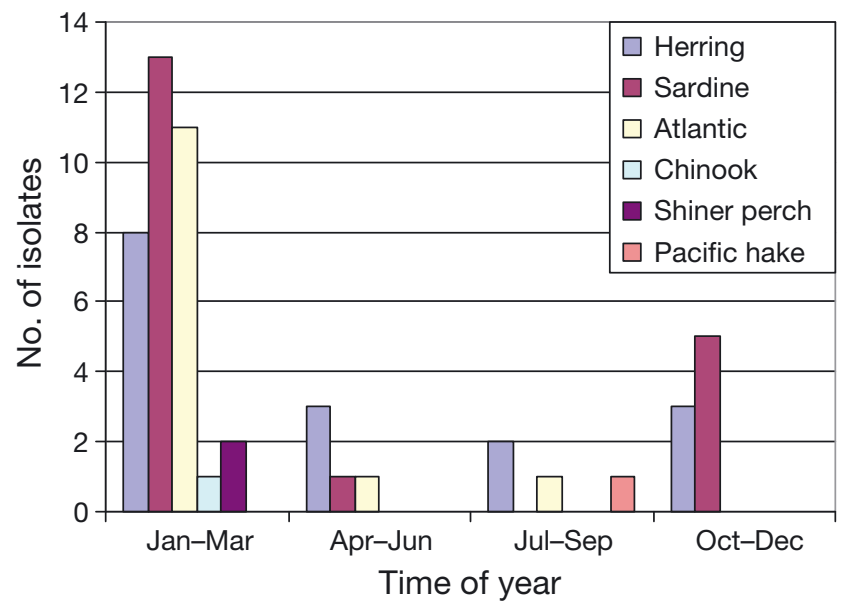

Fig. 2. Annual temporal distribution of viral haemorrhagic septicaemia virus detections observed from the marine waters of British Columbia, Canada, during a 19 yr collection time frame in the deduced amino acid sequence. The nucleotide changes resulting in a non-synonymous change from the consensus are highlighted in red in Fig. 3.

The consensus glycoprotein sequence for each isolate was distinct; however, genetic heterogeneity was confirmed in 3 isolates after repeated amplification and sequencing. Mixed nucleotide positions were observed on the chromatograms for isolates BC 02-229, BC 05-197, and BC 06-037-2. Virus isolate BC 02-229 obtained from a sardine sampled from Hardy Bay, BC, was heterogeneous at position 785, containing either an adenine (A) or a guanine (G). When nucleotide 785 is an $A$, it is identical to sequence type 21 (see Table 3 for a listing of all sequence types), and when it is a $G$ it matches sequence type 14. Isolate BC 05-197 obtained from Pacific sardine sampled in Kitimat Inlet was heterogeneous at position 592, consisting of a cytosine (C) or a thymine $(\mathrm{T})$. When nucleotide 592 is a $\mathrm{C}$, then it 
Table 3. Summary of viral haemorrhagic septicaemia virus isolates collected from 1993 to 2011 in the marine waters of British Columbia, Canada

\begin{tabular}{|c|c|c|c|c|}
\hline $\begin{array}{l}\text { Sequence } \\
\text { type }\end{array}$ & $\begin{array}{l}\text { Isolate } \\
\text { name }\end{array}$ & $\begin{array}{l}\text { Date } \\
\text { collected }\end{array}$ & Location & Host species $^{\mathrm{a}}$ (weight) \\
\hline 1 & BC 93-372 & Sep 1993 & Prince Rupert Harbour & Herring juvenile \\
\hline 2 & ВС 93-390 & Oct 1993 & Campbell River & Herring juvenile \\
\hline 3 & ВC 95-297 & Mar 1995 & Campbell River & Atlantic salmon (3 kg) \\
\hline 4 & BC 95-225 & Aug 1995 & Prince Rupert & Herring juvenile \\
\hline \multirow{3}{*}{5} & ВC $96-265-3$ & Nov 1996 & Campbell River & Herring immature adult \\
\hline & BC $96-265-4$ & Nov 1996 & Campbell River & Herring immature adult \\
\hline & BC 96-265-11 & Nov 1996 & Campbell River & Herring immature adult \\
\hline 6 & ВC 96-265-6 & Nov 1996 & Campbell River & Herring immature adult \\
\hline \multirow[t]{2}{*}{7} & BC $98-012$ & Feb 1998 & Takush Harbour & Sardine \\
\hline & BC $98-250$ & Feb 1998 & Saltspring Island & Atlantic salmon \\
\hline 8 & BC 98-249 & Feb 1998 & Saltspring Island & Herring juvenile \\
\hline 9 & ВC 99-010-3 & Jan 1999 & Gilford Island & Herring juvenile \\
\hline \multirow[t]{5}{*}{10} & ВC 99-001 & Jan 1999 & Beaver Cove, Telegraph Creek & Sardine juveniles and adults \\
\hline & BC 99-UR22 & Jan 1999 & Upper Retreat & Herring \\
\hline & BC 99-017 & Jan 1999 & Echo Bay & Sardine \\
\hline & BC 99-019 & Jan 1999 & Telegraph Cove & Sardine \\
\hline & ВС 99-021 & Jan 1999 & Cramer Passage & Sardine \\
\hline 11 & ВC 99-292 & Apr 1999 & Southern Vancouver Island & Atlantic salmon post-smolts \\
\hline 12 & BC 00-LF & Apr 2000 & Nanoose Harbour & Herring \\
\hline 13 & ВC $00-397$ & Jun 2000 & Hecate Strait & Herring \\
\hline \multirow[t]{3}{*}{14} & $\mathrm{BC} 02-28-6$ & Feb 2002 & Fair Harbour, Kyuquot Sound & Sardine juveniles and adults \\
\hline & ВC 02-033-8 & Feb 2002 & Fair Harbour, Kyuquot Sound & Sardine juveniles and adults \\
\hline & ВC 02-39-4 & Mar 2002 & Discovery Point Nootka Sound & Sardine juveniles and adults \\
\hline 15 & $\mathrm{BC} 02-03$ & Mar 2002 & Arrow Pass & Atlantic salmon post-smolts \\
\hline 16 & BC 02-41-9 & Mar 2002 & Fair Harbour, Kyuquot Sound & Sardine juveniles and adults \\
\hline \multirow[t]{3}{*}{17} & BC $02-41-14$ & Mar 2002 & Fair Harbour, Kyuquot Sound & Shiner perch \\
\hline & BC $02-47-5$ & Mar 2002 & Stopper Island, Barkley Sound & Herring \\
\hline & BC $02-057-2$ & Mar 2002 & Spiller Channel & Sardine juveniles \\
\hline 18 & BC 02-47-21 & Mar 2002 & Stopper Island, Barkley Sound & Herring \\
\hline 19 & BC $02-235-2$ & Nov 2002 & Hardy Bay & Herring \\
\hline 20 & BC 02-232-1 & Nov 2002 & Quatsino Sound & Sardine juveniles \\
\hline \multirow[t]{3}{*}{21} & BC $02-236-3$ & Nov 2002 & Smith Inlet & Sardine juveniles \\
\hline & BC 02-229 & Nov 2002 & Hardy Bay & Sardine adults \\
\hline & ВC $02-231-3$ & Nov 2002 & Hardy Bay & Sardine adults \\
\hline \multirow[t]{2}{*}{22} & BC 04-029-15 & Feb 2004 & Clayoquot Sound & Sardine adults \\
\hline & BC $04-28-1$ & Feb 2004 & Clayoquot Sound & Atlantic salmon (150 g) \\
\hline 23 & $\mathrm{BC} 04-040$ & Mar 2004 & Clayoquot Sound & Atlantic salmon \\
\hline 24 & BC 05-011 & Jan 2005 & Clayoquot Sound & Atlantic salmon (80-90 g) \\
\hline 25 & BC 05-014-2 & Jan 2005 & Clayoquot Sound & Herring juveniles (6.4 g) \\
\hline 26 & BC 05-014-7 & Jan 2005 & Clayoquot Sound & Herring juveniles (34.1 g) \\
\hline 27 & BC $301-1 \mathrm{~A}$ & Feb 2005 & West coast of Vancouver Island & Chinook salmon \\
\hline \multirow[t]{2}{*}{28} & BC 283-1B & Feb 2005 & West coast of Vancouver Island & Chinook salmon \\
\hline & BC 06-37-1 & Feb 2006 & Bedwell Sound & Sardine \\
\hline \multirow[t]{3}{*}{29} & BC $313-1 \mathrm{~A}$ & Feb 2005 & West coast of Vancouver Island & Chinook salmon \\
\hline & BC 06-034 & Dec 2005 & Seymour Inlet & Sardine \\
\hline & BC 06-035 & Feb 2006 & Millar Channel & Sardine \\
\hline 30 & BC 05-197 & Nov 2005 & Kitimat & Sardine \\
\hline 31 & ВC 06-089-1 & Jan 2006 & Rennell Sound, Queen Charlotte Island & Sardine adults \\
\hline 32 & BC 06-089-4 & Jan 2006 & Rennell Sound, Queen Charlotte Island & Sardine adults \\
\hline 33 & BC 06-037-2 & Feb 2006 & Bedwell Sound & Atlantic salmon \\
\hline 34 & BC $07-286-10$ & Jan 2007 & Arrow Pass, Broughton & Atlantic salmon \\
\hline 35 & BC $07-21-2$ & Jan 2007 & Clayoquot Sound & Sardine \\
\hline \multirow[t]{2}{*}{36} & BC 07-14-3 & Jan 2007 & Arrow Pass, Broughton & Shiner perch adult \\
\hline & BC 07-15-7 & Jan 2007 & Arrow Pass, Broughton & Atlantic salmon (250 g) \\
\hline 37 & BC 07-13-2 & Jan 2007 & Arrow Pass, Broughton & Herring juvenile \\
\hline \multirow[t]{2}{*}{38} & BC 08-2816-1 & July 2008 & Port Hardy & Atlantic salmon \\
\hline & BC $09-30-1$ & Jan 2009 & Port Hardy & Atlantic salmon \\
\hline 39 & ВC 09-31-8 & Jan 2009 & Port Hardy & Herring \\
\hline 40 & ВC 09-31-2 & Jan 2009 & Port Hardy & Herring \\
\hline \multirow[t]{3}{*}{41} & BC $10-42-13$ & Mar 2010 & Barkley Sound & Atlantic salmon \\
\hline & BC $10-21-3$ & Mar 2010 & Barkley Sound & Herring \\
\hline & BC $11-19-3$ & Feb 2011 & Quadra Island & Herring \\
\hline 42 & BC 11-191 & Jul 2011 & Bedwell Sound & Pacific hake \\
\hline
\end{tabular}




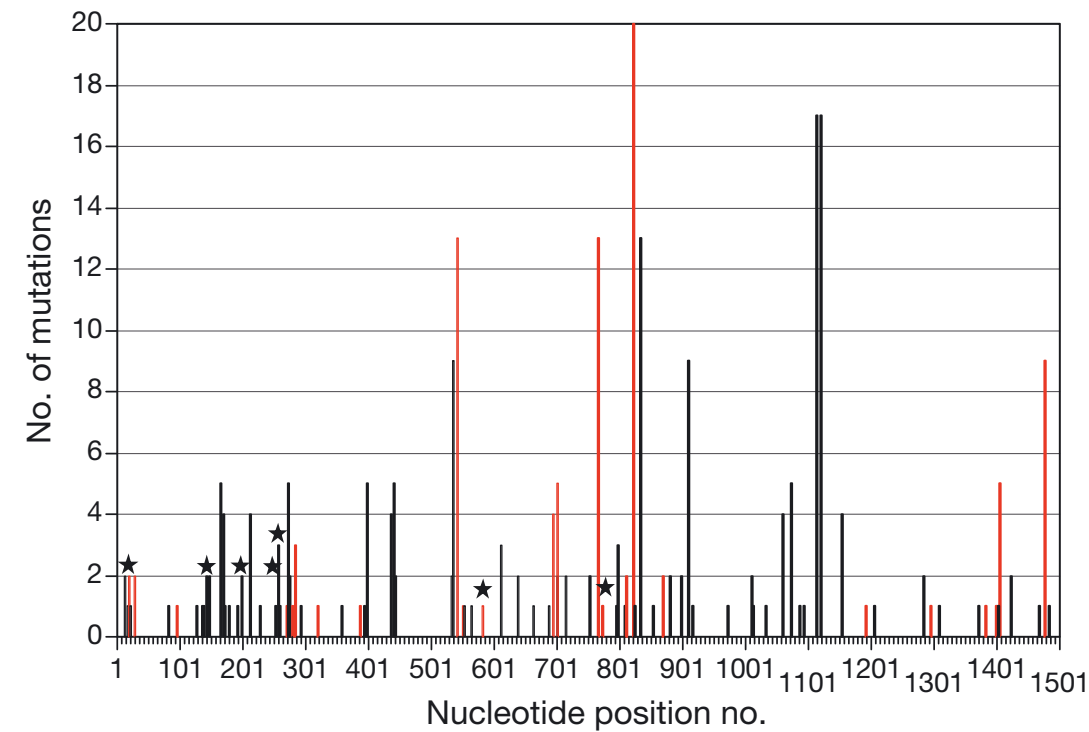

Fig. 3. Distribution of nucleotide differences from the consensus of 42 viral haemorrhagic septicaemia virus (VHSV) full coding glycoprotein (G) gene sequence types detected in marine finfish species in British Columbia, Canada. Red bars show mutations resulting in non-synonymous changes; stars indicate nucleotide positions which showed genetic heterogeneity within an individual isolate

matches sequence no. 36; however, when present as a $\mathrm{T}$, the sequence is unique. Isolate $\mathrm{BC}$ 06-037-2 contained 5 heterogeneous sites, with 2 positions (nucleotides 18 and 216) containing a mixture of $\mathrm{C}$ and $\mathrm{T}$ and 3 positions (nucleotides 174, 261, and 264) containing mixtures of A and G. If positions 18, 174, 216, 261, and 264 are $T, G, T, A$, and A, respectively, then isolate BC 06-037-2 fits into sequence no. 28.

\section{Spatial, temporal, and host relationships of VHSV isolates within sequence types}

The majority $(71 \%)$ of the 42 VHSV sequence types observed throughout $\mathrm{BC}$ were represented by a single isolate consequently occurring at a single location and time. Due to the single datapoint, inferences regarding spatial, temporal, and host associations cannot be drawn. Among the 12 sequence types that are represented by multiple VHSV isolates, none persisted longer than $1 \mathrm{yr}$ from its original isolation date. Among the 12 instances when multiple isolates shared identical G gene sequences, most isolates originated from the same geographic area and time (i.e. multiple isolates per outbreak event; sequence types 5, 10, 14, 21, 22 and 36). However, in some instances, isolates were obtained at different times (sequence types 28,29 , and 38) and/or locations (sequence types 7,17 , and 41 ). In 8 of the 12 sequence types with multiple isolates, no specific host association was observed such that each $\mathrm{G}$ gene sequence type was isolated from multiple host species while the other 4 sequence types were represented by isolates made from single host species (Table 3).

\section{Phylogenetic analysis}

The genetic relationships among the BC VHSV sequences are illustrated in the phylogeny shown in Fig. 4 and Fig. S2 in the Supplement at www. int-res.com/articles/suppl/d104p093_ suppl.pdf. All 42 BC VHSV sequence types grouped into a single clade together with previously published types originating from the North Pacific Ocean and denoted as subgenotype IVa. Due to the BC VHSV isolates' phylogenetic relationship with representative genotype IVa isolates from Washington and Japan, the entire lineage was denoted as IVa. Congruent with previously published phylogenies (Pierce \& Stepien 2012), the North American VHSV sequence types can be further differentiated into 2 sub-genotypes (IVb, IVc) with high posterior probabilities and bootstrap values in the Bayesian and maximum likelihood analysis, respectively. Sub-genotype IVb represents Great Lakes VHSV sequence types and sub-genotype IVc represents VHSV sequence types from the Atlantic coastal waters of New Brunswick and Nova Scotia, Canada. Additionally, each of the 3 genotype IV sub-genotypes are genetically distinct and separate from the European genotypes I to III (Fig. 4) Internal structure was evident within sub-genotype IVa, further resolving genetic relatedness among the sequence types isolated from fish in BC. In some instances, these groupings correlated with the geographic and temporal features of the virus isolates, such that isolates collected from hosts residing in close proximity to one another tended to be similar in sequence and therefore grouped together in the phylogeny.

\section{Association of sequence types in wild and farmed fish}

Among the BC VHSV sample set, 16 virus isolations were made from farmed salmonids that grou- 
Fig. 4. Phylogenetic tree displaying relationships of 42 viral haemorrhagic septicaemia virus (VHSV) glycoprotein gene sequence types from British Columbia, Canada, with representative types from other areas of the North Pacific Ocean, Atlantic coast of North America, Great Lakes region, and Europe to reflect the 4 major VHSV genogroups (I-IV). The complete list of GenBank accession numbers for VHSV glycoprotein coding sequences used in the Bayesian analysis is shown in Table S1 in the Supplement at www.int-res.com/ articles/suppl/d104p093_suppl.pdf. The tree was calculated using the $70 \%$ majority rule in sumtrees (Sukumaran \& Holder 2010), and numbers at branch nodes represent posterior probabilities. The scale bar indicates the number of substitutions per nucleotide site. Parallel phylogenetic analyses using maximum likelihood methods mirror the relationships obtained in the Bayesian analysis (Fig. S2 in the Supplement)

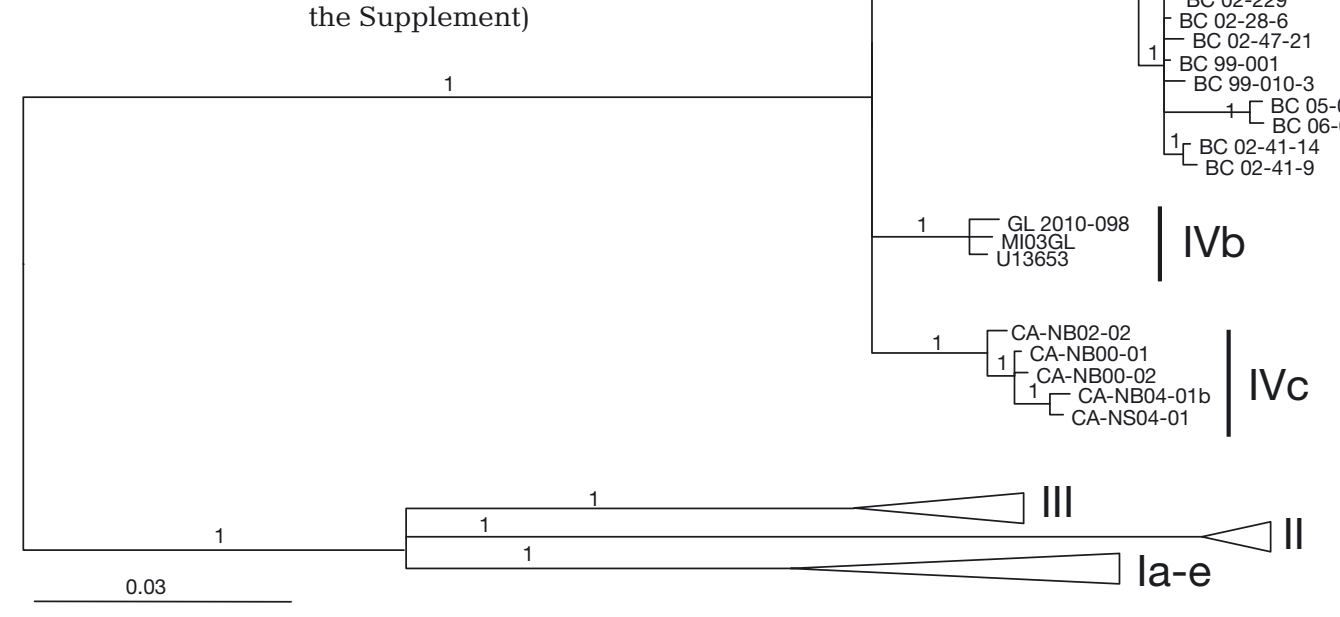

ped into 15 different sequence types. Of these 15 sequence types, 6 (sequence nos. 7, 22, 28, 29, 36, 41) contained virus isolate(s) originating from wild fish species that shared identical G gene sequences to those isolates obtained from farmed Atlantic or Chinook salmon (Table 3). Of the 9 sequence types (nos. 3, 11, 15, 23, 24, 27, 33, 34, 38) unique to farmed salmonids, 5 (nos. 15, 24, 33, 34, 38) grouped into well supported subclades each of which included virus isolates obtained from wild fish. Often virus isolates from wild and farmed fish that are either identical or nearly identical were isolated from fish in close geographic proximity that were sampled within a similar time period. However, in some instances the related or identical sequence types occurring in wild and farmed fish were isolated from geographically distant locations and/ or at different time periods.

\section{Genetic diversity in an outbreak}

Within the dataset, there are 14 separate occasions when 2 or more isolates were collected during a disease investigation (Table S2 in the Supplement at www.int-res.com/articles/suppl/d104 p093_suppl.pdf). In 2 of the 14 cases, only 1 sequence type was observed during an outbreak, while in the remaining 12 cases, multiple sequence types were identified and contained up to 3 different sequence types per sampling event. The greatest pair-wise nucleotide difference between sequence types in an individual disease event was $1.6 \%(24 / 1524 \mathrm{nt})$. In 6 out of these 12 cases, the sequence types isolated from a single event were divergent enough to prohibit the confident placement of these isolates collectively into a sub-group within the IVa sub-genotype. 


\section{DISCUSSION}

This study is the first comprehensive analysis of the genetic diversity and epidemiology of VHSV isolates from the marine waters of $\mathrm{BC}$ since the first detection of the virus in Pacific herring in 1993. Inclusion of $3 \mathrm{VHSV}$ isolates from $\mathrm{BC}$ in a previous investigation, aimed at determining the relatedness of VHSV from other areas of the North Pacific Ocean, suggested that isolates from marine waters spanning from Alaska to California were genetically similar (Hedrick et al. 2003). The phylogenies generated herein clearly reveal that all BC VHSV isolates group into one lineage, previously denoted as IVa, that includes marine isolates from the North Pacific Ocean.

In $\mathrm{BC}$, the majority of the VHSV isolations are from the pelagic species Pacific herring and Pacific sardine. The first detection of VHSV in BC occurred in September 1993 from Pacific herring seine netted at Prince Rupert Harbour following a diesel fuel spill. There were numerous dead and moribund fish reported in the area with visible lesions. It is not possible to determine if the fuel spill was a cause of losses; however, it alerted people to be more observant, resulting in the collection of samples for disease analysis. Since 1998, mass mortality of sardines and herring have been frequently reported at various locations along coastal BC. During these epizootics, VHSV was repeatedly isolated from moribund and fresh dead fish (Table 3). The geographic extent of the losses varied from being quite localized to huge areas covering many square kilometres. Field observations made by experienced herring biologists estimated several of the die-offs involving sardines to be in excess of 5000 metric $t$, with the surface of some inlets being covered with dead and dying fish for distances of over $15 \mathrm{~km}$. The massive extent of these die-off events, corroborated with high mortality in experimental exposures of Pacific herring to VHSVIVa, reflects the extreme virulence of genotype IVa in pelagic finfish species (Kocan et al. 1997, Hershberger et al. 2007)

It is unclear what the drivers for these massive epizootic events are, but undoubtedly they are multifactorial and involve the complex interaction of the host, pathogen and their shared environment. The losses involving the sardines and herring most frequently occurred during the winter and early spring months (Fig. 2) in periods of colder ocean temperatures, with the die-offs being observed in inlets and fjords along Northern Vancouver Island, Haida Gwaii, and the $\mathrm{BC}$ mainland. The seasonal occurrence of these die- off events suggests a strong environmental influence. Colder water temperatures and reduced availability of food, as observed during the winter and spring months, may compromise the hosts' ability to mount a protective immune response to VHSV infection, consequently leaving them more prone to disease. Controlled laboratory studies have demonstrated that VHSV susceptibility of Pacific herring is highly influenced by diet and temperature (Beaulaurier et al. 2012, Hershberger et al. 2013). It is noteworthy that such large scale marine die-off events are not universally seen throughout the infectious range of VHSV-IVa. North of $\mathrm{BC}$, in the marine waters of Alaska, VHSV-IVa-associated mass mortality events in Pacific herring and sardines have been described (Meyers et al. 1994, Marty et al. 1998). However, in the marine waters south of $\mathrm{BC}$, natural VHSV mortality events have not been observed despite the presence of VHSV in these waters (P. K. Hershberger pers. comm.). Furthermore, mass mortality events have not been reported in European wild marine fish stocks from which VHSV has been isolated (Skall et al. 2005).

Although Pacific herring and sardine were the predominant host species infected with VHSV in BC, the virus was also isolated from marine net-pen farmed salmonids. Since its first detection in farmed Atlantic salmon in 1995, VHSV has been detected nearly annually in the BC salmonid aquaculture industry. Genetic typing of these isolates revealed that in 12 of the 16 cases, the virus type identified was either identical or nearly identical to virus isolated from wild marine fish species, suggesting a close relationship between virus of wild and farmed fish. At salmon farm sites, herring and sardines are often observed swimming around and within the net-pen enclosures. Whether drawn to the net-pen facilities as a refuge from predators (e.g. sea lions and seals) or for food, the pelagics have been observed to reside in or around the net-pen area for several months (authors' pers. obs.). VHSV epizootics occurring among these pelagic fish would result in exposure of the farmed salmon to the virus by shedding from the co-habiting pelagics. Shedding rates of VHS diseased herring have been estimated to be in the order of 1.8 to $5.0 \times 10^{8}$ plaque-forming units fish ${ }^{-1} \mathrm{~d}^{-1}$ (Hershberger et al. 2010). Thus, it is conceivable that if large numbers of herring residing in or around a net-pen undergo a VHSV epizootic then the farmed salmon may be subjected to high concentrations of waterborne virus.

Evidence for virus transmission from wild to farmed fish is further provided through field observa- 
tions in conjunction with the temporal occurrence of the genetic types within the various fish populations. Particularly within our dataset, there are 3 examples in which the molecular epidemiology along with field observation reveal virus transmission from a wild marine fish reservoir to nearby farmed salmon. The first representation of a virus transmission event occurred in Clayoquot Sound. Farmed Atlantic salmon smolts (VHSV negative as determined through health checks) were introduced into the marine net-pen site in December of 2003. Post entry, the farmed salmon remained healthy and only background mortality $(<1 \%)$ was observed. One month following the introduction of salmon, Pacific sardines succumbing to mortality and exhibiting signs of VHS disease (i.e. petechial haemorrhaging and exopthalmia) were observed near the net-pens. As the number of dead sardines increased around the net-pen area, slightly increased mortality became evident within the farmed salmon. In February 2004, moribund or dead sardines and Atlantic salmon were collected for viral analysis. Virus isolates (BC 04-029-15 and $\mathrm{BC}$ 04-28-1) were cultured from each of the salmon and sardine and found to be identical in sequence over the entire coding region of the VHSV G gene (sequence type 22). Similar scenarios involving VHS diseased Pacific herring were evident a year later at another farm site within Clayoquot Sound (isolates BC 05-011, BC 05-014-2) as well as in 2010 within a farm site in Barkley Sound (isolates BC 1021-3, BC 10-42-13). In each of the 3 cases, VHSV-free Atlantic salmon were found positive after exposure to either VHSV-positive sardine or herring residing in or around the net-pens.

The transmission of VHSV from a wild marine reservoir to a farmed fish population is not unprecedented. Phylogenetic studies have provided considerable genetic evidence indicating that highly pathogenic VHSV occurring in European rainbow trout aquaculture emerged from a genotype I marine ancestor (Stone et al. 1997, Einer-Jensen et al. 2004, Snow et al. 2004). The adaptation of the marine VHSV to become pathogenic within the aquaculture population was presumably driven by the historical practices of feeding unpasteurized raw marine fish to the farmed rainbow trout (Meyers \& Winton 1995, Dixon et al. 1997, Dixon 1999). Consequently, the observation of VHSV-IVa in farmed Atlantic salmon raises many questions in regard to the pathogenicity of this endemic virus to a non-endemic host and its potential for evolution towards higher virulence. To date, VHSV-IVa isolations in Atlantic salmon, as reported herein, have been associated with cases where there was minimal losses and pathology, suggesting low virulence of type IVa for Atlantic salmon. Nevertheless, as VHSV-IVa is occurring nearly annually in BC farmed Atlantic salmon populations, it is crucial that we understand the pathogenesis of type IVa virus in Atlantic salmon. Current research by J. Lovy et al. (unpubl.) is examining the host susceptibility, transmission dynamics, and duration of infection of VHSV-IVa in Atlantic salmon to help understand the risks associated with the disease.

The $2 \%$ genetic diversity observed among the VHSV isolates presented herein falls within the 1 to $6 \%$ levels observed for full-length G gene sequences within the European genotypes I to III (Einer-Jensen et al. 2004) and the North American type IVc (Gagné et al. 2007). However, the VHSV population structure within $\mathrm{BC}$ is in contrast to that observed for VHSV emerging in the Great Lakes. Within the BC data set, the ephemeral appearance of 42 sequence types over the $19 \mathrm{yr}$ collection period reveals the occurrence of ongoing sequence divergence and lack of a predominant sequence type, while in the Great Lakes, 2 dominant sequence types accounted for $90 \%$ of the isolates collected over a $6 \mathrm{yr}$ period (Thompson et al. 2011). The higher abundance of viral variants observed among the $\mathrm{BC}$ data set in comparison to the Great Lakes isolates is likely reflective of the temporal differences in viral presence between the 2 regions. In $\mathrm{BC}$, historical reports of high mortality observed in Pacific herring and Pacific sardine stocks during the winter months of 1941 and 1942 (Foerster 1941, Tester 1942, Hart 1943), suggest that VHSV may have been present prior to its initial isolation in 1993. In the Great Lakes the earliest detection of VHSV dates to 2003, suggesting that the virus has been present in the marine environment in $\mathrm{BC}$ for a longer period than it has in the Great Lakes.

Despite the long-term association of VHSV with herring and sardines in $\mathrm{BC}$, large-scale mortality events are observed on a yearly basis. In terms of virus evolution, the episodic events observed in wild Pacific herring and sardine provide a unique opportunity to investigate the genetic diversity within a single outbreak. From the data presented herein, multiple sequence types were frequently observed within an isolated mortality event. Analyses of these co-circulating types often revealed a close genetic relationship, with only 1 or 2 bases different over the full $\mathrm{G}$ gene coding sequence (such as with sequence types 5 and 6 , which were isolated from a single dieoff event). The simplest hypothesis for this close association of sequence types within an outbreak is that mutations arise during viral replication in a fish and 
are subsequently introduced and established into other fish associated with the mortality event. Observation of genetic heterogeneity of sequences obtained from single fish as observed in our study and others (Einer-Jensen et al. 2004, Thompson et al. 2011) support the notion of VHSV quasispecies within a single host. In contrast to the presence of sequence types differing by only 1 or 2 bases, it was also revealed in the dataset presented herein that VHSV outbreaks could be defined by sequence types differing in as much as 24 bases (i.e. sequence type 31 vs. 32). The occurrence of such diverse sequence types co-circulating among a die-off event may suggest separate VHSV introductions into the fish population.

In summary, this study provides a genetic analysis of the VHSV that occurred in the marine water of BC since its first detection in 1993. This work revealed a close genetic linkage between VHSV isolates obtained from pelagic finfish species and farmed salmonids, providing evidence for virus transmission from wild to farmed fish. To date, the occurrence of VHSV in BC farmed salmonid populations has been associated with low virulence, with no evidence of farm to farm spread. Nonetheless, aquaculture practices as outlined in the BC Viral Management Plan, such as the frequent removal of moribund or dead fish from net-pens and the rearing of 1 year class per farm site, help to reduce potential risk of virus transmission, adaptation, and ultimately the occurrence of disease in farmed fish populations. Continual monitoring of the VHSV types in both wild and cultured fish populations throughout the marine environment of $\mathrm{BC}$ will be of importance for recognition of potential changes to the VHSV genetic population structure.

Acknowledgements. We thank B. Boyce and D. Morrison (Marine Harvest), P. McKenzie (Mainstream Canada), B. Milligan (Grieg Seafoods), J. Robinson and G. Marty (BC Ministry of Agriculture), S. Saksida (BC Centre for Aquatic Health Sciences), M. Sheppard, I. Keith, H. Manchester, J. Schweigert and S. Dawe (Fisheries and Oceans Canada) for providing samples and background information. We also thank N. Van Steenkiste for technical advice on phylogenetic analyses. This study was funded by Genomics Research and Development Initiative of Fisheries and Oceans Canada.

\section{LITERATURE CITED}

Amos K, Thomas J, Hopper K (1998) A case history of adaptive management strategies for viral hemorrhagic septicemia virus (VHSV) in Washington State. J Aquat Anim Health 10:152-159
Batts WN, Arakawa CK, Bernard J, Winton JR (1993) Isolates of viral hemorrhagic septicemia virus from North America and Europe can be detected and distinguished by DNA probes. Dis Aquat Org 17:67-71

> Beaulaurier J, Bickford N, Gregg JL, Grady CA, Gannam AL, Winton JR, Hershberger PK (2012) Susceptibility of Pacific herring to viral hemorrhagic septicemia is influenced by diet. J Aquat Anim Health 24:43-48

Brunson R, True K, Yancey J (1989) VHS virus isolated at Makah National Fish Hatchery. Fish Health Sect Am Fish Soc Newsl 17:3-4

Dixon PF (1999) VHSV came from the marine environment: clues from the literature, or just red herrings? Bull Eur Assoc Fish Pathol 19:60-65

$>$ Dixon PF, Feist S, Kehoe E, Parry L, Stone DM, Way K (1997) Isolation of viral haemorrhagic septicaemia virus from Atlantic herring Clupea harengus from the English Channel. Dis Aquat Org 30:81-89

Einer-Jensen K, Ahrens P, Forsberg R, Lorenzen N (2004) Evolution of the fish rhabdovirus viral haemorrhagic septicaemia virus. J Gen Virol 85:1167-1179

Einer-Jensen K, Ahrens P, Lorenzen N (2005) Parallel phylogenetic analyses using the N, G or Nv gene from a fixed group of VHSV isolates reveal the same overall genetic typing. Dis Aquat Org 67:39-45

Elsayed E, Faisal M, Thomas M, Whelan G, Batts W, Winton $\mathrm{J}$ (2006) Isolation of viral haemorrhagic septicaemia virus from muskellunge, Esox masquinongy (Mitchill), in Lake St Clair, Michigan, USA reveals a new sublineage of the North American genotype. J Fish Dis 29:611-619

Faisal M, Winters AD (2011) Detection of viral hemorrhagic septicemia virus (VHSV) from Diporeia spp. (Pontoporeiidae, Amphipoda) in the Laurentian Great Lakes, USA. Parasit Vectors 4:2

Foerster RE (1941) The mortality of young pilchards. Fisheries and Oceans Canada. Prog Rep Pac Coast Stn 48:3-8

> Gagné N, Mackinnon AM, Boston L, Souter B, CookVersloot M, Griffiths S, Olivier G (2007) Isolation of viral haemorrhagic septicaemia virus from mummichog, stickleback, striped bass and brown trout in eastern Canada. J Fish Dis 30:213-223

> Garver KA, Dwilow AG, Richard J, Booth TF, Beniac DR, Souter BW (2007) First detection and confirmation of spring viraemia of carp virus in common carp, Cyprinus carpio L., from Hamilton Harbour, Lake Ontario, Canada. J Fish Dis 30:665-671

> Garver KA, Hawley LM, McClure CA, Schroeder T and others (2011) Development and validation of a reverse transcription quantitative PCR for universal detection of viral hemorrhagic septicemia virus. Dis Aquat Org 95:97-112

Groocock GH, Getchell RG, Wooster GA, Britt KL and others (2007) Detection of viral hemorrhagic septicemia in round gobies in New York State (USA) waters of Lake Ontario and the St. Lawrence River. Dis Aquat Org 76: $187-192$

Hall BG (2011) Phylogenetic trees made easy: a how-to manual, 4th edn. Sinauer Associates, Sunderland, MA

Hart JL (1943) The pilchard Sardinops caerulea on Canadian fish grounds with special reference to an unusual abundance of small fish. Trans R Soc Can Ser 3:55-73

Hedrick RP, Batts WN, Yun S, Traxler GS, Kaufman J, Winton JR (2003) Host and geographic range extensions of the North American strain of viral hemorrhagic septicemia virus. Dis Aquat Org 55:211-220 
Hershberger PK, Gregg J, Pacheco C, Winton J, Richard J, Traxler G (2007) Larval Pacific herring, Clupea pallasii (Valenciennes), are highly susceptible to viral haemorrhagic septicaemia and survivors are partially protected after their metamorphosis to juveniles. J Fish Dis 30: 445-458

- Hershberger P, Gregg J, Grady C, Collins R, Winton J (2010) Kinetics of viral shedding provide insights into the epidemiology of viral hemorrhagic septicemia in Pacific herring. Mar Ecol Prog Ser 400:187-193

Hershberger PK, Purcell MK, Hart LM, Gregg JL, Thompson RL, Garver KA, Winton JR (2013) Influence of temperature on viral hemorrhagic septicemia (Genogroup IVa) in Pacific herring, Clupea pallasii Valenciennes. J Exp Mar Biol Ecol 444:81-86

Hopper K (1989) The isolation of VHSV from chinook salmon at Glenwood Springs, Orcas Island, Washington. Fish Health Sect Am Fish Soc Newsl 17:1

Kocan RM, Bradley M, Elder N, Meyers T, Batts W, Winton J (1997) North American strain of viral hemorrhagic septicemia virus is highly pathogenic for laboratory-reared Pacific herring. J Aquat Anim Health 9:279-290

Lumsden JS, Morrison B, Yason C, Russell S and others (2007) Mortality event in freshwater drum Aplodinotus grunniens from Lake Ontario, Canada, associated with viral haemorrhagic septicemia virus, Type IV. Dis Aquat Org 76:99-111

Margolis L (1995) Isolation of North American strain VHS virus from farmed Atlantic salmon. Aquaculture Update 72. Pacific Biological Station, Nanaimo, BC

Marty GD, Freiberg EF, Meyers TR, Wilcock J, Farver TB, Hinton DE (1998) Viral hemorrhagic septicemia virus, Ichthyophonus hoferi, and other causes of morbidity in Pacific herring Clupea pallasi spawning in Prince William Sound, Alaska, USA. Dis Aquat Org 32:15-40

Meyers TR, Winton JR (1995) Viral hemorrhagic septicemia virus in North America. Annu Rev Fish Dis 5:3-24

Meyers TR, Short S, Lipson K, Batts WN, Winton JR, Wilcock J, Brown E (1994) Association of viral hemorrhagic septicemia virus with epizootic hemorrhages of the skin in Pacific herring Clupea harengus pallasi from Prince William Sound and Kodiak Island, Alaska, USA. Dis Aquat Org 19:27-37

Meyers TR, Short S, Lipson K (1999) Isolation of the North American strain of viral hemorrhagic septicemia virus (VHSV) associated with epizootic mortality in two new

Editorial responsibility: Mark Crane,

Geelong, Victoria, Australia host species of Alaskan marine fish. Dis Aquat Org 38: $81-86$

> Pierce LR, Stepien CA (2012) Evolution and biogeography of an emerging quasispecies: diversity patterns of the fish viral hemorrhagic septicemia virus (VHSv). Mol Phylogenet Evol 63:327-341

Ronquist F, Huelsenbeck JP (2003) MrBayes 3: Bayesian phylogenetic inference under mixed models. Bioinformatics 19:1572-1574

> Skall HF, Olesen NJ, Mellergaard S (2005) Viral haemorrhagic septicaemia virus in marine fish and its implications for fish farming - a review. J Fish Dis 28:509-529

Smail DA (1999) Viral haemorrhagic septicaemia. In: Woo P, Bruno DW (eds) Fish diseases and disorders: viral, bacterial, and fungal infections, Vol 3. CAB International, Wallingford, p 123-146

Snow M, Bain N, Black J, Taupin V and others (2004) Genetic population structure of marine viral haemorrhagic septicaemia virus (VHSV). Dis Aquat Org 61:11-21

Stone DM, Way K, Dixon PF (1997) Nucleotide sequence of the glycoprotein gene of viral haemorrhagic septicaemia (VHS) viruses from different geographical areas: a link between VHS in farmed fish species and viruses isolated from North Sea cod (Gadus morhua L.). J Gen Virol 78: 1319-1326

Sukumaran J, Holder MT (2010) DendroPy: a Python library for phylogenetic computing. Bioinformatics 26:1569-1571

Tamura K, Peterson D, Peterson N, Stecher G, Nei M, Kumar S (2011) MEGA5: molecular evolutionary genetics analysis using maximum likelihood, evolutionary distance, and maximum parsimony methods. Mol Biol Evol 28: 2731-2739

Tester AL (1942) Herring mortality along the south-east coast of Vancouver Island. Fisheries and Oceans Canada. Prog Rep Pac Coast Stn 52:11-15

- Thompson TM, Batts WN, Faisal M, Bowser P and others (2011) Emergence of Viral hemorrhagic septicemia virus in the North American Great Lakes region is associated with low viral genetic diversity. Dis Aquat Org 96: $29-43$

Traxler GS, Kieser DK, Richard J (1999) Mass mortaltiy of pilchard and herring associated with viral hemorrhagic septicemia virus in British Columbia, Canada. Fish Health Sect Am Fish Soc Newsl 27:3-4

Wolf K (1988) Viral hemorrhagic septicemia virus. In: Wolf K (ed) Fish viruses and fish viral diseases. Cornell University Press, Ithaca, NY, p 217-249

Submitted: November 6, 2012; Accepted: February 13, 2013 Proofs received from author(s): April 18, 2013 